\section{Making things worse}

SIR - So John Maddox thinks (Nature 353, 13; 1991) that the AIDS epidemic may have a "silver lining", does he, because of the work it has allowed Simon LeVay to conduct on the relative sizes of neurons in the hypothalamus of straight and gay men? Apart from this being an insulting way to describe a disease that is probably going to wreck the lives of hundreds of thousands of people, he may also find very few gay men and lesbians who will be quite as pleased at the sort of research he is discussing.

We do not live in a society in which homosexuality is considered as acceptable or normal; rather, gay men and lesbians are harassed, oppressed and generally treated as second-class citizens purely on the basis of our sexuality. In Britain, we are about the only group against which there has been a record of overt direct legislation by the present government and, while more liberal attitudes may be expressed in California, gay men and lesbians everywhere are basically having a very rough time of it. Consequently one would have hoped that scientific establishments would have given some thought to the ethical implications of their research and the social environment it will enter.

The suggestion that Christians would stop defining homosexuality as sinful if it could be shown to be hard-wired is laughably naive. Most Christians traditions maintain that humans are born flawed and to lead a 'good' life one must fight to overcome these defects, whatever they are. And frankly, having my status altered from that of being sinful to that of being ill or neurologically abnormal doesn't seem like much of an improvement to me.

Research of this nature will always be presented in terms of variation from the 'normal'. I'm sure plenty of readers of the article thought that asking what makes a gay man gay was a perfectly acceptable question but have never asked themselves what makes them straight. The very phrasing of the question reinforces the perception of homosexuality as something alien and inferior, as did the title "Is homosexuality hard-wired?" Research of this comparative kind on social minorities will almost always be used to support the prevailing ideologies and prejudices one simply has to look at the way IQ data along with neurological and anatomical measurements were used in both the nineteenth and twentieth centuries to support the inferior positions in society given to women and non-Caucasians. And the fact that the current research was conducted by a gay man does not make it any better - a gay man is just as capable of shooting himself in the foot as anyone else.

The reality of life for a gay man or a lesbian is that our freedom to enjoy the same civil liberties as straight people is very limited as we are constantly confronted by the bigotry of those around us, and work such as that of Simon LeVay will serve only to reinforce this bigotry by presenting society with ridiculously simplistic 'explanations' of why we are different from 'normal' people. It is also not unlikely that such work will also encourage people to think in terms of a 'cure' for being gay, by the use of drugs that act on the neurons in the hypothalamus. This isn't a fanciful suggestion, as thousands of gay men and lesbians who lived through so-called treatment by such techniques as aversion therapy, electric shock treatment, drug administration and incarceration in mental hospitals can testify. There is more to be considered in scientific research than solely the academic interest that will be generated.

\section{University of Edinburgh,} Edinburgh, UK

\section{Rustum Roy replies}

SIR - You take a whole page in News and Views (Nature 351, 13; 1991) to advance a case that I am "making a mountain of a molehill" without providing your readers with any factual background on the "issue". Your attack is full of errors and misinterpretations.

At the request of Tim Beardsley of Scientific American, I looked at a paper by Bianconi et al. in Nature 1 and a piece by $\mathrm{Mann}^{2}$ in the same issue. The first described an experiment in precipitating small CdS crystals in an organic gel. Both connected this modest observation by tortured reasoning to "biological composite materials such as bones, teeth and shells"1... "analogous to those produced by natural biomineralization" 2 . Its significance was alleged to be in . . . "the controlled fabrication of superior composites, ceramics and polymers ..."2 and "in the synthetic mimicking of biominerals" 2 .

As a science policy analyst, I thought these claims to be wildly exaggerated and connected more to a new poorly thoughtthrough push in "biomimetic biomaterials" among US agencies than to any new science. I wrote a two-page policy paper $^{3}$ and sent it, privately, to agencies, policy makers and journals. The dual thrust of my case was summarized clearly thus: "The case at hand involves two separate errors: (1) exaggeration of the significance of a particular piece of research by grossly overstating its connection to biomaterials; (2) a total failure to read or refer to the literature by the authors and journal editorial process

I continued: "This is NOT a case of cheating, fraud, malice, etc., . . No one is alleged to have acted out of any but the 'normal' processes of science reporting today." It went on later: "I reiterate: there is absolutely zero suggestion of any intentional error on anyone's part. But then there's something very wrong with the system especially because John Maddox and Stephen Mann at Nature are so extraordinarily competent."3

Now compare these facts to your leading article. Your first sentence claims that I charged "plagiarism", exactly the opposite of what I claimed (that they had not read the literature). And as Editor of Nature you go on record that my decrying "exaggeration of the significance of research" and "failure to read the literature" is a "needless fuss about empty issues". History will prove you as wrong on this as it did when you tried to make a molehill out of the mountain in the Baltimore case.

Third, you achieve an extraordinary feat of hybridizing two scientists, Della M. Roy and myself, by referring to Della M. ("Rustum") Roy.

Materials Research Laboratory,

RUSTUM RoY

Pennsy/vania State University,

University Park,

Pennsylvania 16802-4801, USA

1. P. A. Bianconi et al., Nature 349, 315 (1991)

2. S. Mann, Nature 349, 285 (1991).

3. Rustum Roy, "Exaggeration of the Potential of Biomimetic Biomaterials," paper circulated privately, 1-8 (March 1991)

\section{Lice and easy}

SIR — Daedalus (Nature 352, 761; 1991) proposes an interesting new theory of DNA 'parasitism', but misses an important point regarding parasite survival strategy. Lice are highly host- and location-specific, spending their entire life-cycle in a selected niche of their host's anatomy. On the host's death then, the louse is not able, as Daedalus suggests, "simply [to] go off and find a new host", because, with the very rare exception of those like the sheep foot louse $^{1}$, transmission of lice from host to host occurs only when the host's bodies are in contact. In the cuckoo, for example, lice are transferred from one partner to the other at the time of copulation ${ }^{2}$.

MATTHEW PLAYFORD

MASAO KAMIYA

Department of Veterinary Parasitology, Hokkaido University, Sapporo, Japan

1. Blood, Radostits \& Henderson Veterinary Medicine, (6th Edn) 955 (Bailliere Tindall, London, 1983).

Cheng, T.C. General Parasitology, (2nd Edn). 639 (Academic, New York, 1986) 